\title{
建築設備の保全作業における安全管理に関する 理論的研究

\author{
THEORETICAL STUDY ON SAFETY MANAGEMENT FOR \\ BUILDING SERVICES MAINTENANCE WORK
}

\begin{abstract}
高草木 明*
Akira TAKAKUSAGI

The purpose of this study is to formulate the mathematial expression of the risk of the accidents supposed to occur during the building services maintenance work, and to obtain the method to establish the safety manegement basis. During the maintenance work term, accidents are supposed to occur accidentally following by the Poisson distribution. The arrival rate of it expresses the accident occurance frequency that can be decreased boundlessly by the safety effort. On the other hand, as for the severity of the accidents, introducing the concept "danger level", the distribution of the damege is formulated. The distribution is expressed by the logarithmic normal distribution that includes the "danger level" as a parameter. The risk is defined by the convolution of the distibutions of the accident occurunce frequency and the severity. Finally, the method to lay down the safety effort level as a safety manegement basis by evaluating the risk is presented.
\end{abstract}

\section{Ke ywords: bulding services, maintenance Fork, safety management, accident, severity, rish}

建築設備, 保全作業, 安全管理, 災害, 災害強度, リスク

はヒめに

建築界はフローからストックの時代に移ったといわれ、 保全の高品質化が重要な課題となっている。保全は場当 たり的なものでなく、保全計画に則って行われるへきで ある。建築設備の保全計画では、予防保全、オーバーホ 一ル、更新等における保全方策の合理化が主たる課題と なる”。一方、保全行為そのむのは現場での作業であり、 常に災害が発生する危険性をはらんでいる。高品質な保 全のためには、保全方策の合理化だけでなく、保全作業 における災害防止のための安全努力が不可欠であり、そ のための方針も保全計画に盛り込まれて然るべきである。

建築設備の保全現場での安全努力の具体的手法は、一 般の建築工事現場の手法と多くが共通するものである。 これらは、H. H. Heinrichの産業災害防止論 ${ }^{2}$ を噶矢とす る災害防止の原則、災害の因果モテル・安全管理モデル 等の研究 ${ }^{3)} \sim^{6)}$ や、人間エラーの防止に焦点を当てた人 間信頼性工学 ${ }^{7}$ 、また、建築分野における災害の調査研 究尚のなどにより導かれたものといえよう。

問題はこれにどの程度の努力（あるいは安全対策コス
ト）を注ぐへきかという基本方針の策定にある。安全に は、ある一現場の安全もその現場だけの問題ではなく、 社会的意味を持つという性格がある。このため、安全管 理の基準は、災害の頻度と強度を併せて確率的に表現し たリスクの提示を伴うものでなければならない。このよ うな観点からの既往研究はこく少ない。産業災害につい

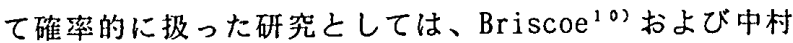

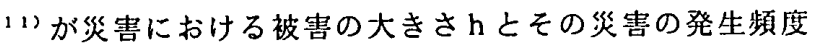
$\mathrm{p}$ との関係を $\mathrm{k}=\mathrm{h}^{\mathrm{n}} \mathrm{p}$ ( $\mathrm{n}$ と $\mathrm{k}$ は定数) のべき関数で記 述することを提案し、花安が建設工事労働災害の被害強 度・規模特性に関する統計分析の研究 ${ }^{12)}$ において、この 関係から被害の大きさを確率変数に変換し、ご簢単な 確率分布式を導いている（注）という程度であろう。

そこで本研究は、建築設備の保全の安全管理計画手法 の確立に向けて、建筑設備の保全作業に対して災害リス クの理論式を導き安全管理基準の設定手法を得ることを 目的とし、先ず、建築設備の保全における安全管理のあ り方について概略検討した上で、災害頻度、災害強度に ついて確率分布を導き、更にこれらを重量してリスクの

\footnotetext{
*NTTファシリティーズ 博士(工学) NTT POWER AND BUILDING FACILITIES, Dr. Eng.
} 
理論式を導出し、リスクの評価によって、安全努力への 投資の程度を計画する手法を示した。

\section{1. 趣築設備の保全における安全管理のあり方}

災害の発生要因として、不安全状態（環境要因）と不 安全行動（人的要因）とがあげられる。今日の一般の建 筑物新築工事においては、労僖安全衛生法・労僖安全衛 生規則等の規制や事業所における安全整備が行き届き高 水準なものとなっており、検討課題としては不安全行動 による災害対策に重点が置かれているといわれる ${ }^{13} 。$

建築設備の保全には、いわゆるビルメンテナンスにお ける日常的保全から、改修工事までが含まれる。高所作 業、高压電力やガスを使用する機器についての作業、酸 欠を生じ易い閉所作業等、その作業環境は多岐に亘る。 既存建物での作業であり、その状況が作業環境として与 条件となる。設計において保全作業性に十分な配虑がな されていない場合、保全員にとって不安全状態となる。 文献 ${ }^{14)}$ に多くの事例が示されているように、それは少な くないのが実状である。また、建築設備保全の作業員は 高齢化の傾向にあり、今後ともこれは進むものと考えら れている(15)。加䍅によって危険に対する生理的反応が衰 えるから安全環境整備は一層重要となる。建築設借の保 全計画には環境要因・人的要因の両面から安全努力の計 画が盛り込まれるへきである。

作業環境に関する安全努力の方法としては、長期的に は、建築設備の新築時の設計において保全作業性に一層 配虙すること、安全に関わる技術開発を推進すること、 短期的には安全管理者による安全点検を行い現場での改 善をはかることなどが挙げられる。また、不安全行動に ついては、作業前の人選・教育、作業中の安全点検によ る不安全行動の指摘・是正等が必要である。これらの安 全努力の程度を合理的に計画することが安全管理の重要 な役割である。

このような安全管理のためには、リスクの構造を明ら かにして、安全管理基準を設定する必要がある。ハイン リッヒらは㶤害の頻度率と強度率とを分けて災害防止を 論している2》。また、Crouch とサilsonは、リスクを、 リスク二確率め重大性と定義し（8は重畳効果を表す記 号であるが、ある適当な尺度を用いての単純な乗算では ないとしている)、確率とは起こりやすさの指標であり、 重大性（severity）とは損害のひどさを表す主観的指標

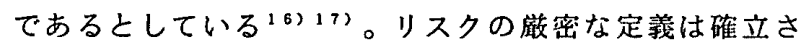

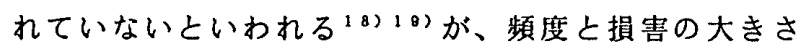
(強度)によって構成されるものといえよう。以下、建 築設備保全の作業において知覚され得るリスクの範囲内 で災害頻度と災害強度とを個別に数理的に検討したうえ で、そのリスクの理論式を導出し管理基準の設定方法を
示す。

非な記号

$\nu$ : 災害発生率

$\mathrm{T}_{M}$ : 保全作業期間

$\mathrm{w}$ ：期間 $\mathrm{T}_{\mathrm{M}}$ における災害発生件数

$\mathrm{p}_{\mathrm{i}}(\mathrm{w})$ ：期間 T $\mathrm{M}$ において災害が $\mathrm{w}$ 回起こる確率

$z$ : 災害強度に関わる危険度

$\mathrm{L}(\mathrm{z})$ : 災害によって生じる損害

$\mathrm{L}_{0}$ : 損害 $\mathrm{L}$ の初期值 $(=\mathrm{L}(0))$

$\varepsilon(z): \Delta z$ おたりの損害增加率

$A(z)$ : 損害增加率 $\varepsilon$ の摇動項

$\mathrm{p}(\mathrm{L})$ ：危険度 $z$ における損害しの確率密度分布

$\mathrm{P}(\mathrm{L})$ ：危険度 $\mathrm{z}$ における損害 Lの確率分布

$\mathrm{L}_{\mathfrak{p}}$ : 危険度 $z$ における損害のメティアン

$\mathrm{L}_{\mathrm{m}}$ : 危険度 $\mathrm{z}$ におりる損害 $\mathrm{L} の$ 平均

$\mathrm{L} ＼textrm{r}$ 単位時間当たりの平均損害

$\mathrm{f}$ : 経済性の観点からの災害発生率管理値

$\mathrm{r}$ : リスク

\section{2. 災蹇の䁰度}

災害の発生頻度は、100万労働時間当たりの災害件 数である「災害度数率」や、労偟者 10000 人当たりの 災害発生件数である「災害千人件效」が尺度として利用 されている20)。これらは、生じた災害の結果について統 計的に評価する尺度である。建築設備の保全計画におい て、安全努力を計画する場合、災害発生頻度の確率分布 を想定する必要がある。

労謿災害は偶発的に発生すると考えられるから、ポア ッソン分布に従って発生すると考えられる。とすれば、 ある作業工程において、災害が時間 $\Delta \mathrm{t}$ の間に起こる確

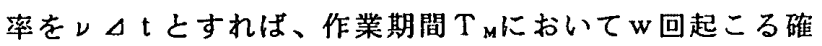
率 $\mathrm{p}$ （（w）は次式で表される。

$$
p_{t}(w)=\frac{\left(\nu T_{M}\right)^{w}}{w !} \text { exp }\left(-\nu T_{M}\right)
$$

災害の発生頻度を低くするためには上式のレを小さく する安全努力が必要である。

ハインリッヒのドミノ理論では災害連鎖の五つの要因、

(1)家系と社会環境

(2)人的欠宿

(3)不安全状態・不安全行動

(4) 災害

(5)侮害

をこの順でドミノ倒しのドミノに例えて、中心要因をな す不安全状熊と不安全行動の除去によって先行要因の作 用の無効化がはかれるとしだ2。

建築設備の保全作業において災害頻度を低くするため 
には、作業員の人選、作業に先だつ安全教育、危険予知 活動、作業中の巡回・点検（いわゆる安全パトロール） 21)22)、作業の自動化232等によって不安全状態や不安全 行動の発生を抑制する努力がなされる。また、建築設備 の設計において、竣工後の保全作業の安全性について配 虑することも不安全状態の除去のために重要である。

これらの安全努力によって、不安全状態と不安全行動 は抑制・低隇され、(1)式の災害発生率レはいくらでも小 さくすることができる。しかし、安全努力には費用がか かる。従って、安全管理の計画においては、災害頻度之 災害強度（災害によって被る損害の程度）を併せたリス

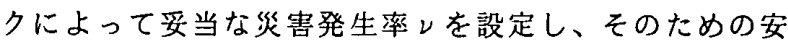
全努力費用の投資が計画されることが適当であろう。

\section{3. 炎害の強度}

\section{3ー1 ハインリッ七の法則 ${ }^{2)}$}

ハインリッヒの” Industrial Accident Prevention" では、潜在的有傷災害の頻度に関するデータから、災害 の強度の比率を $1 ： 29: 300$ とした。これはハイン リッヒの法則と呼ばれ、同書の災害の因果に関するドミ ノ理論とともに広く知られている。この比は同一の人間 に類似した災害が 330 回起こるとき、そのうち 300 回は傷害を伴わず、29回には軽い傷害が、1回には重 い傷害が伴うことを示しており、平均的場合についての みあてはまるとしている。この比率は、稀な重い事故の 原因分析だけによる災害防止対策は誤った安全指針を導 くことになりやすいことを示し、今日の現場でのいわゆ るヒヤリ・ハットの管理等の実践につながっている。

この比率に関して、全ての様式の災害に適用できるも のではなく、全種類の災害の原因と様式の平均を表すも のであることが強調されている。災害の頻度を增す原因 と強度を增す原因とは異なるものであることがその理由 とされている。この説明に、米国の安全管理者が事故の 頻度を減少させることに取り組んできた結果、その副産 物として重大事故が減少するであろうという期待がはず れ、度数率は低下したが強度率低下には効果が小さかっ たことを挙げている。また、全米安全協会による、災害 の強度の災害様式（運搬、転落、電気等）別割合の統計 テータによれば、運搬災害は永久全労働不能障害の 5.6 \%に過ぎないが、一時全労働不能障害の $24.3 \%$ 、永久 一部労働不能の $20.9 \%$ を占めている。一方、電気災害 は永久全労働不能障害の $13.4 \%$ を占めるが、軽い障害 は全災害様式における比率としてはこく少ない。これら の㬰態例から、重い障害を発生する環境と軽い障害を発 生する環境とは異なるであろうということを新たな結論 としている。

以上の既往研究の見解を踏まえ、災害の強度の数理モ
テルを以下に考える。

\section{3-2 災害強度モデル}

災害の原因には不安全状態と不安全行動とがある。不 安全行動は災害発生の頻度を增す要因となるが、災害の 強度を增す要因には殆どならないと考えることができる。 不安全行動によって生じる災害における傷害の強度は不 安全行動をなした環境に大きな影響を受ける。例えば、 吹き抜けパイプシャフトでの作業を考える。作業員に注 意力が足りなかったり、キャットウオークが不足してい たりすれば転落事故発生頻度は高くなる。そこから転落 したとき落下距離が小さけ机ば傷害は小さいことが多く、 深く落下すれば賃害が大きくなることが多い。また、動 力制御盤での結線作業において、十分なテーピングを急 り作業を進めれば、短絡事故の頻度が高くなる。短絡事 故が生じたとき、電圧や配線用途によって人身への被害 や物損の程度が異なる。転落した場合の落下距離や短絡 を起こしたときの電压や配線用途のような災害の強度に かかわる危険度を $z$ で表す。災害によって生ずる物的損 害あるいは人身傷害の程度 (以下、これを損害という) を $z$ の関数としてL $(z)$ で表す。

危険度 $z$ が大きくなれば、それにつれて損害 $\mathrm{L} （ \mathrm{z})$ が大きくなる。危険度 $\mathrm{z} に お け る \Delta z$ あたりの損害増 $\triangle \mathrm{L}$ を

$\Delta \mathrm{L}=\mathrm{L}(\mathrm{z}+\Delta \mathrm{z})-\mathrm{L}(\mathrm{z})$

とする。

危険度 $\mathrm{z}$ における損害 L $(z)$ に対する $\Delta \mathrm{z}$ あたりの 損害增加率 $\varepsilon(z)$ を考えると、

$$
\varepsilon(\mathrm{z})=\lim _{\Delta \mathrm{z} \rightarrow 0} \frac{\Delta \mathrm{L}}{\mathrm{L}(\mathrm{z}) \Delta \mathrm{z}}=\frac{\mathrm{dL}(\mathrm{z}) / \mathrm{d} \mathrm{z}}{\mathrm{L}(\mathrm{z})}
$$

となる。

Weberの法則によれば、ある強さS $S$ 刺激を与え、続い て強さ $S+\Delta S$ の刺激を与えるとき、感覚の最小強度 (just noticeable difference) が生じるのに必要な最 小の $\Delta S$ に対して、 $\Delta S / S=$ 一定という関係が成立す る。危険度 $z$ の大きさの評洒は、この法則を踏まえ、作 業環境について、その危険性を安全管理者の感覚に与え る刺激と捉え、安全管理者が作業環境を診断するとき、 災害が生じたと仮定した場合に感覚的に予測される損害 の程度を、知覚し得る損害の増分毎に等間隔で評点とし て加点してゅくものと考えることとする。この感覚の強 度を危険度 $\mathrm{z}$ とする。ここで安全管理者の作業環境部断 によって感覚的に予測される損害とは仮想的な損害であ り、後にその実体は明らかになる。このような想定とす れば、損害增加率 $\varepsilon(z)$ は危険度 $z$ によらず平均的に 一定值 $\varepsilon$ と考えられる。とすれば損害Lの奨化は、

$$
\frac{d L(z) / d z}{L(z)}=\varepsilon
$$


または、

$$
\frac{\mathrm{d}}{\mathrm{d} z} \log \mathrm{L}(\mathrm{z})=\varepsilon
$$

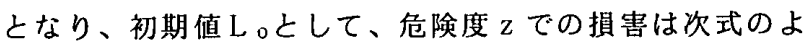
うに指数関数的に增加することとなる。

$$
\mathrm{L}(\mathrm{z})=\mathrm{L}_{0} \exp \left(\begin{array}{ll}
\varepsilon z
\end{array}\right)
$$

損害增加率 $\varepsilon$ は、実際の事故を考えれば、被害を受け る対象物の価値や個々の作業員の生理的反応による危除

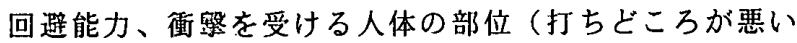
と大きな傷害を受ける）などの影響を受けるため平均值 のまわりでランダムに変化すると考えられる。そこで に摇動項 A $(z)$ を加えると（4）式は、

$$
\frac{\mathrm{d}}{\mathrm{d} z} \log \mathrm{L}(\mathrm{z})=\varepsilon+\mathrm{A}(z)
$$

となる。これを皘分すれば、

$\log \mathrm{L}(z)-\log \left(\mathrm{L}_{\circ} \mathrm{e}^{\varepsilon z}\right)=\int_{0}^{z} \mathrm{~A}(z) \mathrm{d} z$ となる。右边の皘分を $\Delta \mathrm{z} て ゙$ 分割して考えると ${ }^{24)}$ 、

$$
A n=\sum_{j=1}^{n} \int_{(j-1) \Delta z}^{j \Delta z} A\left(z^{\prime}\right) d z^{\prime}=\sum_{j=1}^{n} a_{j}
$$

と表される。ここでa;はランダムな分布を持つから、こ れらが独立に、平均値 0 で等しい分散 $\sigma^{2} \Delta z$ をもつ確率 変数であると考えると、中心極限定理を適用できる。す なわち、

$$
\log \mathrm{L}(z)-\log \left(\mathrm{L}_{\circ} \mathrm{e}^{\varepsilon z}\right)=\mathrm{An}
$$

は、 $\mathrm{n} \Delta \mathrm{z}=\mathrm{z} て ゙ \Delta \mathrm{z} \rightarrow 0$ とした極限で、次式で与えら れる確率分布をもつことになる。

$$
\begin{aligned}
& \mathrm{p}(\mathrm{L})=\frac{1}{\mathrm{~L} \sigma \sqrt{2 \pi z}} \\
& \cdot \exp \left[-\frac{\left|\log \mathrm{L}-\log \left(\mathrm{L}_{\circ} \mathrm{e}^{\epsilon z}\right)\right|^{2}}{2 \sigma^{2} \mathrm{z}}\right]
\end{aligned}
$$

すなわち、危険度 $\mathrm{z} て ゙ の$ 損害 $\mathrm{L}$ の分布（確率密度分布） は上のような対数正規分布で表される。

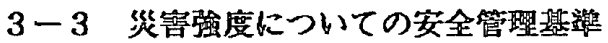

危險度 $\mathrm{z}$ は、安全管理者の作業現場の猃断による危険 度の評価点である。これを $0 ， 2 ， 3 ， \cdots 0 ， 10$ の段 階で考えることとする。(12)式における損害Lは、1〜 10 の範囲で捉えることとする。 $z=0$ のときの L、す なわち初期值は $\mathrm{L}_{0}=1$ であり、 $z=10$ のとき $\mathrm{L}=10$ となるように損害增加率 $\varepsilon$ を与えると、 $\varepsilon=0.2302$ 64 となる。このとき、（5）式より危険度 $\mathrm{z}$ と損害 $\mathrm{L}$ (z) の関係を図示すると、図1のようになる。これは 安全管理者が作業現場の危険性を評価するときの評洒指

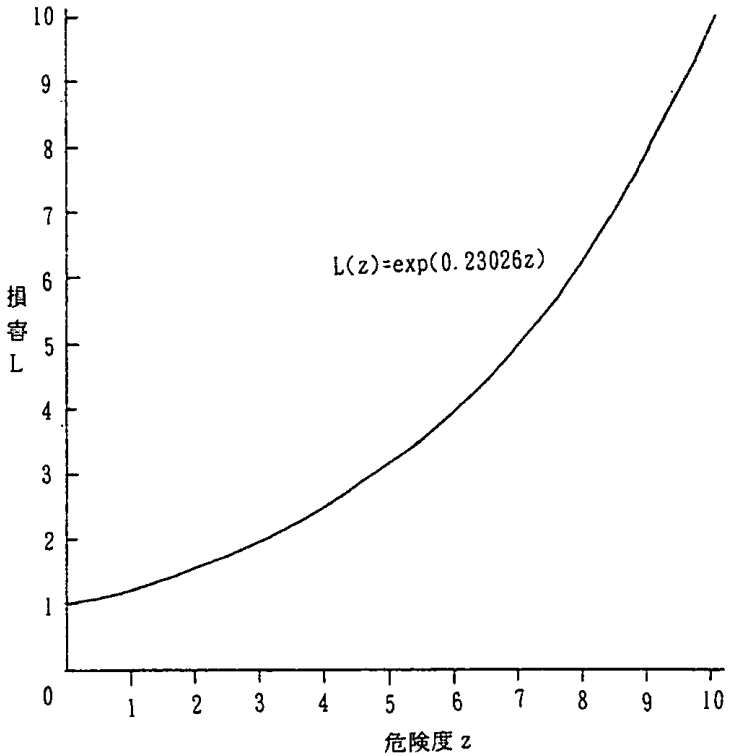

図 1 危険度 $z$ と損害 $\mathrm{L}(z)$ の関係

標の定義といえるものである。

損害増加率 $\varepsilon$ の摇動の大きさを表す偏差 $\sigma$ については、 （10）式で表される危険度 $z$ での損害 L の分布を与える 対数正規分布の形状に影響する。この值を危険度 $z$ が 1 〜 10としたとき、損害 L が $0.01 \sim 10000$ 程度の範 囲に広がるという観点から選定し $\sigma=0.5$ とする。この とき、 $\mathrm{z}=1 ， 5 ， 10$ の 3 個の L の確率密度分布を図 2 に示す。危険度が大きくなると災害の強度率が高まる ことが明確に表現される。また、同じく $z=1 ， 5 ， 1$ 0 の場合の $\mathrm{p}$ （L）を積分した分布関数 P ( L ) を図 3 に示す。

$\mathrm{P}(\mathrm{L})=0.5$ のときの $\mathrm{L}$ の值、すなわちメディン

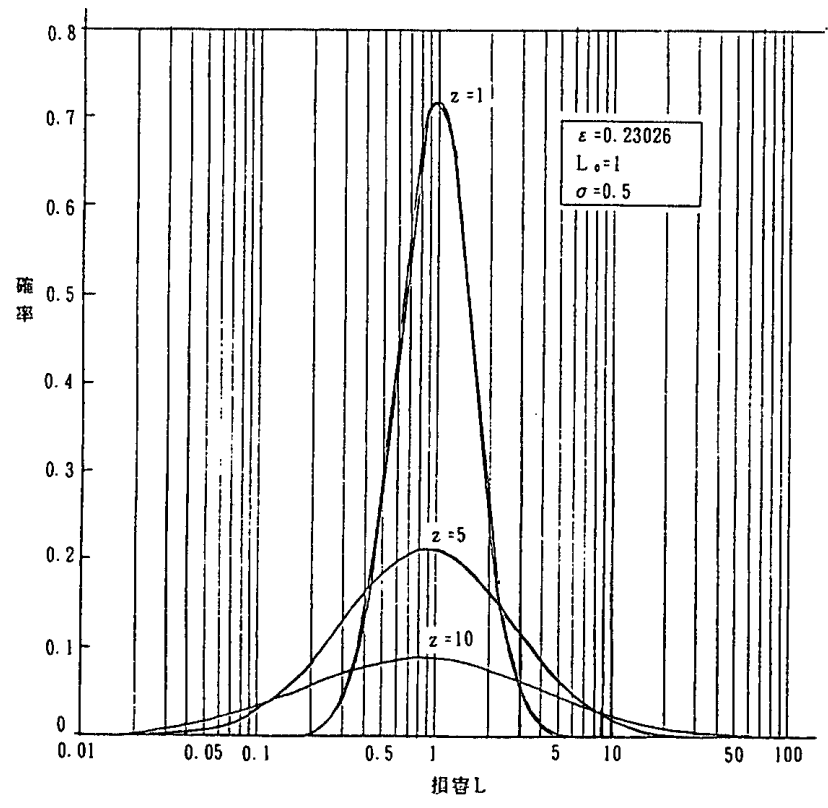

図 2 損害 $\mathrm{L}$ の確率密度分布 $\mathrm{p}$ （L） 


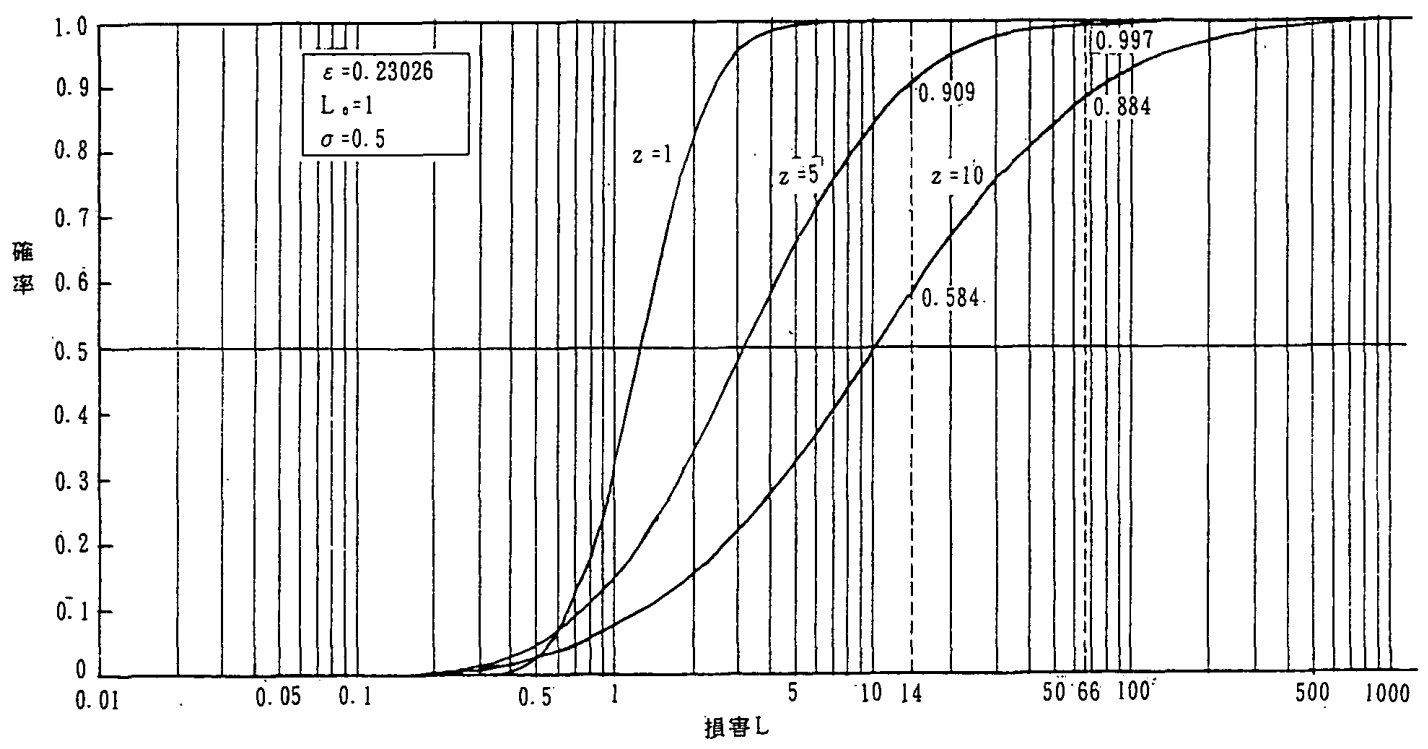

図 3 損害 $\mathrm{L}$ の分布関数 P ( L )

が図 1 におけるL（1），L（ 5 ），L（１０）の值と なる。メディアンL $\mathrm{p}$ は次式で表される。

$$
\mathrm{L}_{\mathrm{P}}=\mathrm{L}_{0} e x p(\varepsilon z)
$$

作業現場で経験する災害の半数が $\mathrm{L} \mathrm{P}$ 以上の損害の災害 ということになる。（11）式は（5）式と一致し、安全管 理者が危険度 $z$ を評洒する際の想定損害はこれが基準と なる。 Z は過去の統計データから決めることができる。 損害 $\mathrm{L} の$ 平均值 $\mathrm{L}$ m は次式で表される。

$$
\mathrm{L}_{\mathrm{m}}=\mathrm{L}_{\circ} \exp \left(\left(\varepsilon+\sigma^{2} / 2\right) \mathrm{z}\right)
$$

$z$ と $\mathrm{L}_{\mathrm{m}}$ の関係を図 4 に示す。事故の損害の統計分析に おいて、一件あたりの平均損害と $z$ の関係はこのように なる。 $\mathrm{z}$ は過去の統計の平均損害から決めてもよい。

ハインリッ七の災害強度比率は、1：29：300= $0.003: 0.088: 0.909$ であるから図3の綎軸 をこの比で分けて対応する損害 $\mathrm{L}$ をると、 $z=5$ の場 合、 $\mathrm{L}=14$ で $\mathrm{P}=0.909$ となり、 $\mathrm{L}=66$ で $\mathrm{P}=0.909+0.088=0.997$ となる。すなわち、 $z=5$ をハインリッヒの比率を対応させる基準とすれば、 ハインリッヒの比率における「重い傷害」はここで示し たモテルでは損害 $\mathrm{L}>66$ の災害に、「軽い伤害」は $66 \geqq \mathrm{~L}>14$ の災害に相当する。損害 $\mathrm{L} \leqq 14$ の場合

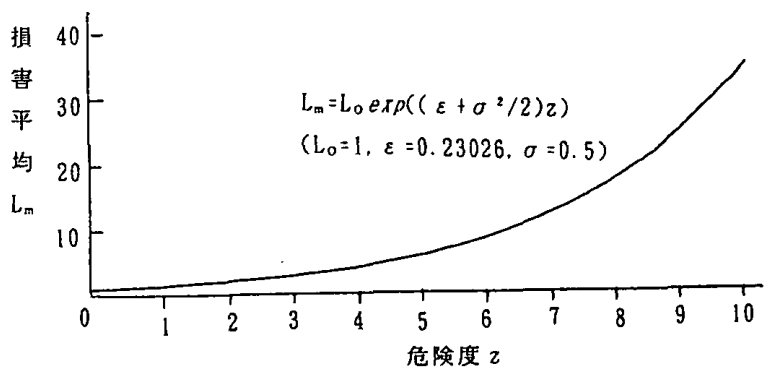

図 4 損害の平均値 $\mathrm{L}_{\mathrm{m}}$ と危険度 $\mathrm{z}$ の関係
は「傷害の無い災害」とみなすこととなる。 $z=1$ の場合では、ほほ $100 \%$ が $<14$ となる。 $z=10$ の場合には、L>66が $11.6 \%$ となり、66 $\geqq \mathrm{L}>14.0$ が $30 \%$ ～ $\mathrm{L} \leqq 14$ が $58.4 \%$ の比率と なる。これは $\sigma=0.5$ とした場合の例である。 $\sigma$ の值を 変えれば損害Lの分布におけるLの值の広がりの範囲が 変わってくる。実際の災害による椇害は、軽傷から、労 働損失日数によって評価される傷害、身体傷害を伴う災 害、死亡、複数の死亡まで幅広い20)。従って、Lの範囲 はこの例のように0．01〜1000 程度の設定が適当 であろう。

これを基準として、保全作業を請け負う会社などが年 間の事故データの災害強度比率を分析すれば、現状の作 業環境における災害強度率の観点からの危険度の実態を 評価することができる。また、経年変化を追うことによ って、保全作業環境の変化を把握することも可能となる。

\section{4. リスクと安全管理基準}

災害頻度は安全対策費用をかければ、安全技術向上、 安全教育、現場での安全点検などによって、いくらでも 低くすることが可能である。一方、災害強度は危険度 $z$ によってほほ表現され、それは技術の向上によってある 程度改善が可能であるが、対象作業で取り扱うエネルギ 一や危険物の程度に大きな影響を受け限界がある。

大規模工業プラントのように、対象作業で取り扱うエ ネルギーや危険物の予期せ女解放を生じたとき予想され る損害が著しく大きければ災害発生率レをこく小さくす るように大きなコストをかけて対策が講じられる。一方、 フィールドアスレチックのように、不安全行動による危 険度 $z$ がこく小さいことを前提にある程度高い災害発生 
頻度を容認して施設環境を設計する場合むある。建築設 備の保全作業はこれら両極端な場合の間にある。

災害発生率 $\nu$ (12) 式の損害の平均值 $\mathrm{L}_{\mathrm{m}}$ より、単位 時間あたりの平均損害 L, は、

$\mathrm{L}_{\mathrm{r}}=\nu \cdot \mathrm{L}_{0} \cdot \exp \left(\left(\varepsilon+\sigma^{2} / 2\right) z\right)$

となる。し，を安全対策費用と損害額との対応による経済 的観点から、ある值に設定して管理するとすれば $\nu$ は $z$ の関数となって、

$$
\nu(z)=\frac{\mathrm{L}_{r}}{\mathrm{~L}_{0}} \exp \left(-\left(\varepsilon+\sigma^{2} / 2\right) z\right)
$$

となる。これが最低限の災害発生頻度の管理目標値とな るといえよう。

安全性は当事者だけの問題ではないから、その基準に は経齐性の観点からだけでなく社会的容認が必要である。 このためのデモンストレーションとしては、設定した安 全管理基準において損害の大きさ毎のリスクを提示する 必要があろう。ここでリスク $\mathrm{r}$ を「災害発生頻度 $\mathrm{f}$ 、危 険率 $z$ の現場での、作業期間 $\mathrm{T}_{M}$ における、損害 L以上の 災害の期待件数」と定義する。
（14）式の単位時間あたりの損害期待値をL，とするよ うな管理を行っている場合の $\nu(\mathrm{z})$ を する。災害は到着率 $\mathrm{f}$ のポアッソン分布に従って発生す るとする。災害発生率 $\mathrm{f}$ の現場で、時間 $\mathrm{T} M$ において $\mathrm{w}$ 回 の災害が発生する確率は、

$$
\frac{\left(\mathrm{f} \mathrm{T}_{\mathrm{M}}\right)^{\mathrm{w}}}{\mathrm{W} !} \exp \left(-\mathrm{f} \mathrm{T}_{\mathrm{M}}\right)
$$

であり、w件の災害について損害がL以上である期待件 数は、

$$
w \circ \int_{L}^{\infty} p(L) d L
$$

である。リスク rはこれらを重畳して、

$\mathrm{r}\left(\mathrm{f}, \mathrm{Z}, \mathrm{T}_{M}, \mathrm{~L}\right)=\sum_{w=1}^{\infty} \frac{\left(\mathrm{f} \mathrm{T}_{M}\right)^{w}}{\mathrm{w} !} e x p\left(-\mathrm{f}_{\mathrm{M}}\right)$

$$
\cdot w \cdot \int_{L}^{\infty} p(L, z) d L
$$

となる。図 5 は、同図中に示したような条件を設定して リスクを計算した例である。

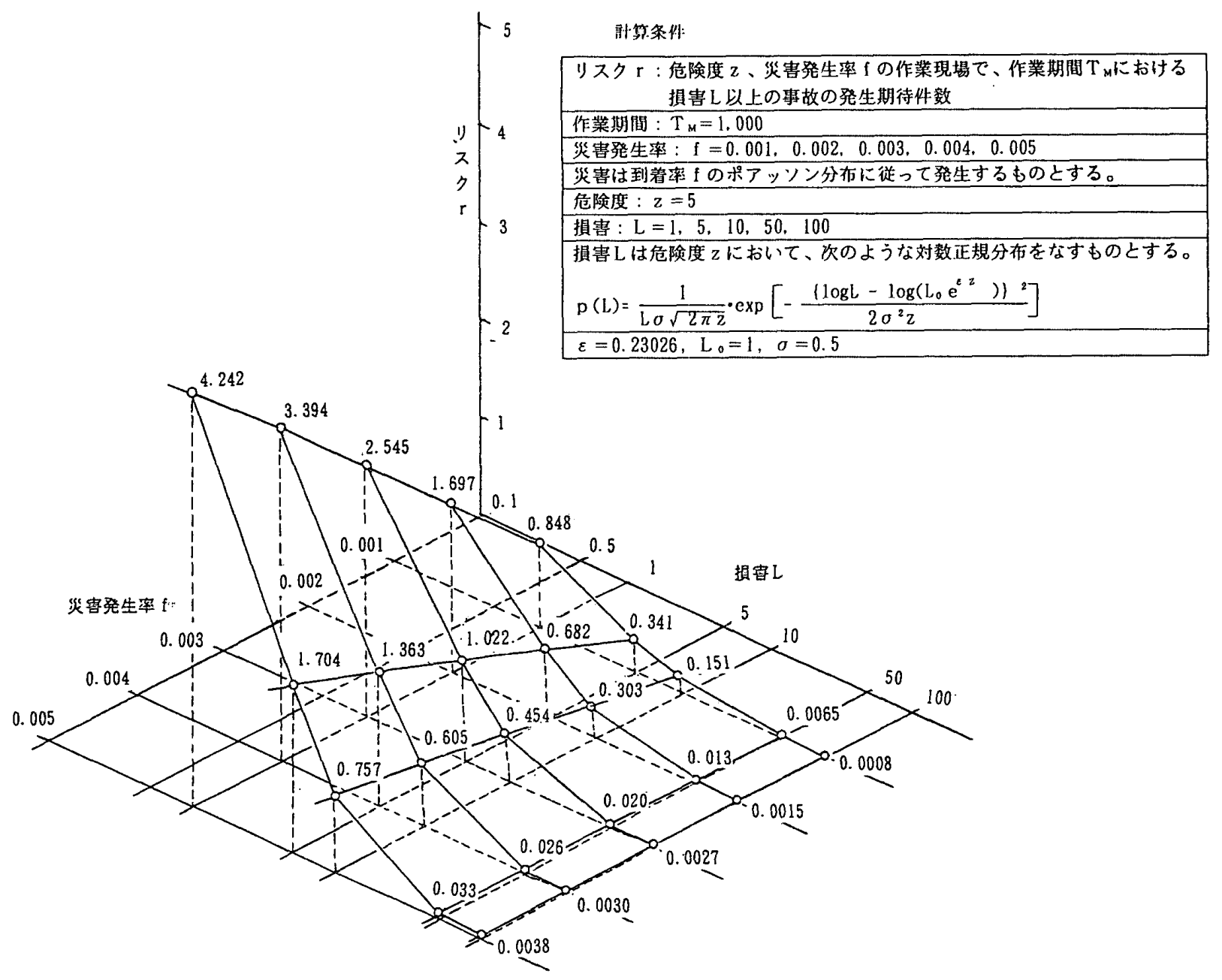

図 5 リスクの計算例 
災害は損害の大きい場合が問題である。損害が大きい 場合のリスクは、頻度について（14）式のように経済性 から管理を行うとすれば、危険度 $\mathrm{z}$ が大きい程大きくな る。例えば、フィールドアスレチックと損害の期待値が 同じとなるような安全努力を建筑設備保全現場に与えた としても、リスクが異なる。社会的容認を得るための条 件とはならない。従って、重大事故についてのリスクを （15）式より検討し、これが容認できないとすれば災害 発生率レを更に小さくなるよう設定して安全管理目標值 としなければならない。

\section{結 論}

建築設備の保全計画においては、保全作業における安 全努力の計画を盛り込むべきであり、そのためには安全 管理の基準を設定する必要がある。

安全管理の目標は、先ず、災害の頻度を小さくするこ とである。設備設計における保全作業性への配虑の向上 や安全関連技術開発、作業員の人選・教育等によって災 害の原因となる不安全状態と不安全行動の発生を抑制す るとともに、安全管理者による作業現場の安全点検で、 それを低減することができる。これらによって災害頻度 は低くなる。災害はポアッソン分布に従って発生するむ のとし、安全努力によってその到着率である災害発生率 はいくらでも低くし得ることを論示した。

安全管理上、災害頻度とともに災害強度を考えること が重要である。災害強度についてはハインリッヒの法則 のように強度比率によって論じられてきた。ここでは、 災害による損害を連続量と捉え、危険度という概念を導 入して、損害の分布が対数正規分布で表され、その分布 の状況は危険度によって変わることを示した。

建築設備の保全現場の危険度は作業環境と作業内容に よって唁断評価されるものである。作業環境の改善など によってある程度の改善は可能であるが短期的安全努力 では限界がある。現場毎の危険度の診断結果によって、 災害頻度低減への努力の程度を判断するべきである。頻 度と重大性とを統合した概念がリスクである。本論文で は最後に災害頻度と災害強度とを重畳しリスクを理論式 で表現して、安全管理基準の設定手法を示した。

\section{(注)}

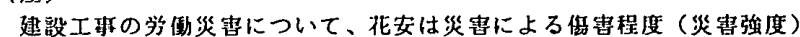
と、一つの災害による目倡者数（災害規模）について炎害報告のデータ を分析し、被害の大きさ $\mathrm{h}$ とその発生頻度 $\mathrm{p}$ との関保は $\mathrm{k}=\mathrm{h}{ }^{\mathrm{n}} \mathrm{p}(\mathrm{n}$ と $\mathrm{k}$ は定数、nは大规模災害の発生の潜在的危険性を表す指摽として使用 できるとしている）のへき関数で記述できることを示している。この関 係式は、ハインリッ七の 1：29：300の法則のような統計的規則性

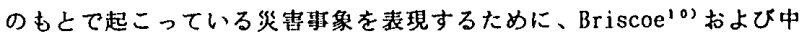
村"いによって提案されたものである。花安は更にこの閣係から、被宫の

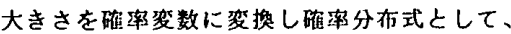

$$
\begin{gathered}
F(h)=1-\left(h / h_{c}\right)^{1-n} \\
h \text { cは炎害规模の下限值 }
\end{gathered}
$$

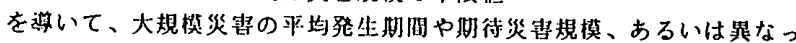
た期间の被害規模の推定なとを行っている122。

\section{文 解}

1)高草水叨：空調設供の予防保全に関する解析的研究，日本建築学会計画 系論文報告集第 430 告, 1991 他

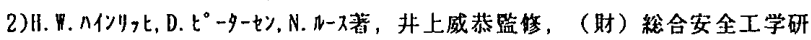
労所絸訳：ハインリッ七産業災传防止論、海文堂，1982

3)安全工学泓会粯: 安全工学調坐 5 人身災叟, 海文堂, 1982

4) J. Surry: Industrial Accident Research, University of Tront. 1968 5)F. E. Bird, Jr. , G. J. Germain:Damege Control, Institute Press, 1966

6)D. Petersen:Techiques of Safety hanegement, HcGraw-Hill Book Comp any. 2nd Ed. 1978

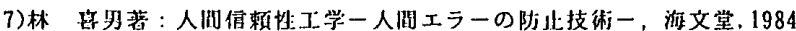

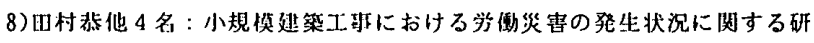

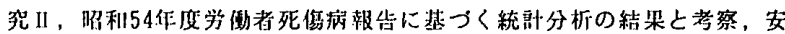

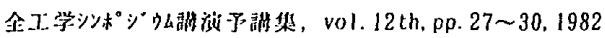

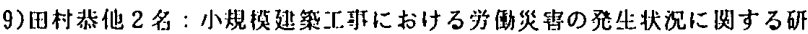

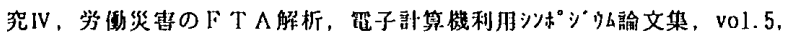
pp. 127 132, 1983

10)G. J. Briscoe:Risk Manegement Guide SSUC-11, Energy Research and development Administration, 76 45/11, 1977

11) 中村林二郎：安全性の一考察 (I) 危除性, 安全工学, vol. 20, №. 3, pp. $120 \sim 126,1981$.

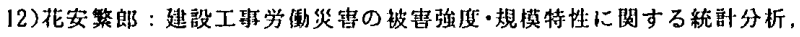
七木学会論文集, No. 462/VI-18, pp. 131 140,1993.3

13)綝㚼正治：建设の安全管理一不安全行助のメカニズムと文の防此一， 㻎工図春, 1983

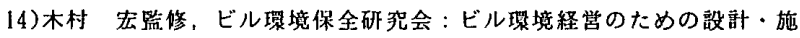
エへからず集 パート1〜3，オーム社，1990.1992

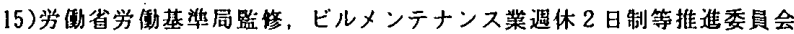
粯 : ビルメンテナンス業における学譈洔間短樎の現状と今後の方向， 大葪省印剧局，1990

16)E. A. Crouch, R. Wilson:Risk/Renefit Analysis, Ballinger Publishing Co., Cambridge, MA, 1982

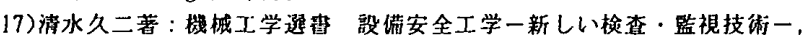
装莽房, 1989

18)乱井利明糏：现代リスクマネジメント事興，同文馆，1988

19)武非 照：リスク・マネジメント総論，中央経济社，1987

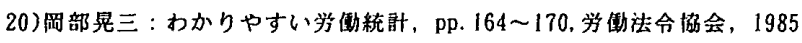

21）中川親正：危険予知剖練と黒板 K Y 活動，施工，№. 205, pp. 57 62, 1983

22)田辺桓久：建筑現場の安全管理，建策士と実務，vol. 5, No. 5. pp. 43 49. 1982

23)森安研：エレクトロニクス利用による建設技術高度化システムの開発， 土木学会䜽文集, No. 385, pp. 29 37, 1987

24)寺本 英：ランダムな現象の数学、吉岡望店，1990

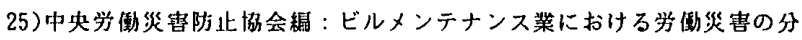

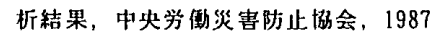

（1995年 6 月21日原稿受理，1995年10月24日採用決定） 